\title{
Physico-Chemical and Functional Properties of Functional Yoghurt Made With Different Types of Whey Protein Concentrates (Wpc).
}

\author{
M. E. Shenana ; M.B. El-Alfy ; G.F. El-Nagar; and A.E. El-Barbary \\ Dairy Sci., Dept., Fac., of Agric., Moshtohor, Benha University, Egypt \\ Corresponding author: meshenana@fagr.bu.edu.eg
}

\begin{abstract}
Functional yoghurt was made using different types of whey protein concentrate (WPC). The chemical, physical, microbiological and sensory quality of the produced functional yoghurt were studied. The obtained results reveled that slight differences were observed for acidity, $\mathrm{pH}$, TS, protein, fat and TVFA either for storage periods or between the treatments. Also, the obtained results reveled that T8 (functional yoghurt made with particulated whey protein at $\mathrm{pH}$ 5) recorded higher content of TVFA and acetaldehyde followed by T10 (functional yoghurt made with commercial whey protein concentrate powder) either when fresh or during the interval storage periods. The previous results reflected the good properties of physical characteristic of the produced functional yoghurt through increasing the viscosity, WHC and reduce the synersis which affected by the amount of added wpc. On the other hand, the sensory evaluation results indicated that all the produced functional yoghurt were good in their characteristics. The highest scores were recorded after 7 days of storage at $5^{\circ} \mathrm{C}$. Also, T9 and T10 which contain 2 and $3 \%$ wpc recorded 93.33 and 94.33 , respectively.
\end{abstract}

Key words: functional yoghurt, WPC, TVFA, phyico-chemical properties.

\section{Introduction}

Yoghurt is one of the best Known fermented dairy products which contain probiotic. Yoghurt is defined by the codex Alimentarius 2003 as a coagulated milk product that results from the fermentation milk by lactic acid bacteria i.e Streptococcus thermophilus and Lactobacillus delbrueckii subsp. bulgaricus.

Yoghurt products have achieved considerable economic importance worldwide owing to their high nutritional image and it has many health benefits such as improving lactose intolerance, anticholesterolemic impacts and reducing risk cancers and other benefits related to probiotics bacteria.....etc. (Laiho et al., 2017). The allegedly hypercholesterolemic effect of milk fat and the desire to ensure overall good health have led consumes to demand reduced fat milk dairy products, mainly including yoghurt, to reduce the risk of coronary heart disease (Sandoval, et al., 2004).

Demand for low milk fat / fat free milk with similar sensory properties with conventional full-fat products. Additional of functional ingredients such as whey protein concentrate (WPC) may improve overall quality of low-fat yoghurt. It is well known ability of (WPC) to support formation of whey protein aggregates which highly improve physical properties of yoghurt (Mikal et al., 2012).

Whey is considered a valuable product because of its soluble proteins and its high levels of amino acid, B vitamins, lactose and salts.(Barbosa et al., 2010). High nutritional quality, potent biological activity and unique functional properties are the foremost attributes of whey proteins (wps) that help sustain interest in their utilization, not only in the food industry but also in allied areas such as the pharmaceutical and bio-medical field (Bhattacharjee et al., 2006).

So, the aim of this study, to use whey protein concentrate (WPC) for manufacture of functional yoghurt for their nutritional and functional properties and to examine the effect of adding different concentration of (WPC) as a fat replacers on the chemical, physical and functional properties of the produced yoghurt.

\section{Materials and methods}

\section{Materials}

Bacterial strains and ingredients:-

a- Whey: Cheddar cheese whey used in this study was obtained from Arab Dairy Co (kaha, kaliubia Governerate, Egypt) and was used for making WPC.

b- Milk: Fresh mixed milk (cow's and buffalo's) were obtained from the heard of Faculty of Agriculture, Moshtohor, Benha University, Egypt.

c- Whey protein concentrate powder was obtained from Davisco Foods International, Inc, 11000Weast 78 the Street, Suite 210 Eden Prairie, Minnesota and parched from local markt.

d- Yoghurt starter cultures consisting of Lactobacillus delbrueckii subsp bulgaricus and Streptococcus thermophiles were obtained from Chr. Hansen's Laboratories, Copenhagen, Denmark and parched from local market.

\section{Preparation of whey protein concentrate by Ultrafiltration: \\ Whey protein concentrate (WPC) was prepared using Ultrafiltration technique as follows: $\mathrm{pH}$ of whey adjusted to (6.5), the whey}


concentrated using cross-flow zirconiumtitanium ceramic membranes $(50 \mathrm{kDa}$ cut-off and $0.020 \mathrm{~m}^{2}$ effective membrane areas). The inlet and outlet pressures were adjusted and controlled to 3.0 bar, and 5.0 bar, respectively. The temperature was maintained at $40^{\circ} \mathrm{C}$. The concentration process stopped when the whey reached to $\sim 14-15 \%$ total solids.

\section{Preparation of whey protein / carrageenan particulate:}

The method of Shenana et al., (2007). Was used for preparation of whey protein particulate as follows: (a) sodium carrageenan was added to the whey retentate at a rate of $0.1 \mathrm{~g} 100 \mathrm{~g}(\mathrm{w} / \mathrm{w})$. The $\mathrm{pH}$ was adjusted to $\mathrm{pH} 5$ as a treatment and $\mathrm{pH} 3$ using $6 \mathrm{~N}$ HCL. (b) the whey retentate containing the carrageenan was heated at $85^{\circ} \mathrm{C}$ for $30 \mathrm{~min}$, and then homogenized at $60^{\circ} \mathrm{C}$ using 2 stages laboratory homogenizer (Rannie, Copenhagen) at 20 and $5 \mathrm{MPa}$ for the $1^{\text {st }}$ and $2^{\text {nd }}$ stage, respectively and (c) the homogenized retentate/ carrageenan mixture was then centrifuged at $5000 \mathrm{G}$ for $10 \mathrm{~min}$. The precipitate was considered as particulate whey protein/carrageenan concentrate (PWPC).

\section{Manufacture of functional yoghurt:}

Fresh mixed milk was standardized to fat content $\sim 3 \%$ (full) and $\sim 1.5 \%$ fat (low). and used for manufacture of functional yoghurt according to the method described by Tamime, (1978). Treatments were prepared as follows:-

C1: Control (full-fat standardized mixed milk cows and buffalos $(1: 1) \sim 3 \%$ fat $)$.

C2: Control (low-fat mixed milk cows and buffalos (1:1) $1.5 \%$ fat).

T1: Low-fat mixed milk cows and buffalo's (1:1) 1.5\% fat $+2 \%$ with whey protein.

T2: Low-fat mixed milk cows and buffalo's (1:1) 1.5\% fat $+3 \%$ with whey protein

T3: Low-fat mixed milk cows and buffalo's (1:1) 1.5\% fat $+2 \%$ with whey protein concentrate.

T4: Low-fat mixed milk cows and buffalo's (1:1) 1.5\% fat $+3 \%$ with whey protein concentrate.

T5: Low-fat mixed milk cows and buffalo's (1:1) 1.5\%fat + $2 \%$ with particulated whey protein concentrate at $\mathrm{pH} 3$.

T6: Low-fat mixed milk cows and buffalo's (1:1) 1.5\%fat + $3 \%$ with particulated whey protein concentrate at $\mathrm{pH} 3$.

T7: Low-fat mixed milk cows and buffalo's (1:1) 1.5\%fat + $2 \%$ with particulated whey protein concentrate at $\mathrm{pH} 5$.

T8: Low-fat mixed milk cows and buffalo's (1:1) $1.5 \%$ fat + $3 \%$ with particulated whey protein concentrate at $\mathrm{pH} 5$.

T9: Low-fat mixed milk cows and buffalo's (1:1) $1.5 \%$ fat + $2 \%$ commercial whey protein concentrate powder.

T10: Low-fat mixed milk cows and buffalo's (1:1) $1.5 \%$ fat $+3 \%$ commercial whey protein concentrate powder.

\section{Analytical methods:}

Total solids, ash, fat and total protein were determined according to the AOAC (2012). Titratable acidity was determined according to the methodology described by BSI (2010). $\mathrm{pH}$ values were measured using a digital laboratory $\mathrm{pH}$ meter (model HANNA pH 213 instruments) with combined glass electrode. Total volatile fatty acids (TVFA) contents were determined by the direct distillation method as described by Kosikowski, (1984). Acetaldehyde content was determined according to the method described by Lees and Jago (1969).

\section{Microbiological examinations:}

Total viable counts (TVC) of the produced functional yoghurt were determined as described by IDF (1991). Yeasts and moulds counts were done as described by IDF (1990). Coliform groups were detected according the methods of APHA (1992).

\section{Rheological analysis:}

Both synersis and water holding capacity (WHC) were estimated according to modified method of Keogh and O'Kennedy (1998). The apparent viscosity was measured according to Petersen et al., (2000). The viscosity of the produced functional yogurts was measured, after stirring the product for 60s, using a Brookfield viscometer model RVDVE (Brookfield Engineering Laboratories Inc., Middleboro, MA) at $10^{\circ} \mathrm{C}$. Samples were tested using spindle no. 4 and data were taken as duplicate at a spindle rotation of $12 \mathrm{rpm}$.

\section{Sensory evaluation:}

Sensory properties of the produced functional yoghurt with wpc were done according to the scheme of (Tamime and Robinson, 1999) when fresh and during the storage periods up to 21 days by 10 staff of dairy sci. Dept. faculty of agri; Benha univ., Egypt.

\section{Results and discussion}

\section{Coagulation time:-}

The effect of adding different percentage and different types of wpc on the coagulation time of functional yoghurt are presented in table (1). The obtained results revealed a slight decrease of coagulation time of yoghurt by increasing the wpc addtion, this may be due to the presence of whey protein which increase the activity of starter culture bacteria. The results are in accordance with El-Alfy et al., (2018). 
Table 1. Coagulation time of functional yoghurt made with different percentage of WPC.

\begin{tabular}{|c|c|c|c|c|c|c|c|c|c|c|c|c|}
\hline \multirow[t]{2}{*}{ Replicates } & \multicolumn{12}{|c|}{ Treatments } \\
\hline & C1 & $\mathrm{C2}$ & T1 & $\mathbf{T 2}$ & T3 & T4 & T5 & T6 & T7 & T8 & T9 & T10 \\
\hline \multicolumn{13}{|c|}{ Coagulation time / h } \\
\hline $1^{\text {st }}$ replicate & 3.36 & 3.27 & 3.07 & 3.16 & 3.16 & 3.20 & 3.15 & 3.17 & 3.11 & 3.17 & 3.19 & 3.10 \\
\hline $2^{\text {nd }}$ replicate & 2.49 & 2.42 & 2.30 & 2.35 & 2.39 & 2.45 & 2.37 & 2.40 & 2.52 & 2.37 & 2.52 & 2.46 \\
\hline $3^{\text {rd }}$ replicate & 3.26 & 3.20 & 2.59 & 3.12 & 3.09 & 3.15 & 3.11 & 3.14 & 3.04 & 2.55 & 3.10 & 3.02 \\
\hline
\end{tabular}

C1: Control (full-fat standardized mixed milk cows and buffalos (1:1) 3\%fat).

C2: Control (low-fat mixed milk cows and buffalos (1:1) 1.5\% fat).

T1: Low-fat mixed milk cows and buffalos (1:1) 1.5\% fat $+2 \%$ with whey protein.

T2: Low-fat mixed milk cows and buffalos (1:1) $\sim 1.5 \%$ fat $+3 \%$ with whey protein.

T3: Low-fat mixed milk cows and buffalos $(1: 1) \sim 1.5 \%$ fat $+2 \%$ with whey protein concentrate.

T4: Low-fat mixed milk cows and buffalos $(1: 1) \sim 1.5 \%$ fat $+3 \%$ with whey protein concentrate.

T5: Low-fat mixed milk cows and buffalos $(1: 1) 1.5 \%$ fat $+2 \%$ with particulated whey protein concentrate at $\mathrm{pH} 3$.

T6: Low-fat mixed milk cows and buffalos $(1: 1) 1.5 \%$ fat $+3 \%$ with particulated whey protein concentrate at $\mathrm{pH} 3$.

T7: Low-fat mixed milk cows and buffalos $(1: 1) 1.5 \%$ fat $+2 \%$ with particulated whey protein concentrate at $\mathrm{pH} 5$.

T8: Low-fat mixed milk cows and buffalos $(1: 1) 1.5 \%$ fat $+3 \%$ with particulated whey protein concentrate at pH5.

T9: Low-fat mixed milk cows and buffalos (1:1) $1.5 \%$ fat $+2 \%$ commercial whey protein concentrate powder.

T10: Low fat mixed milk cows and buffalos (1:1) $1.5 \%$ fat $+3 \%$ commercial whey protein concentrate powder.

Chemical composition of functional yoghurt:

Acidity and $\mathbf{p H}$ values:-

Table (2) shows the average levels of acidity and $\mathrm{pH}$ of functional yoghurt with different percentage of wpc compared with the control low-fat and full-fat content. The mean values of acidity of the T5 and T10 were slightly higher than those obtained for the control and other treatments when fresh and along the storage periods up to 21 days at $\sim 5^{\circ} \mathrm{C}$. This may be attributed to the acidity of wpc used in the both two treatments. Titratable acidity of all treatments increased gradually all over the storage periods up to 21 days due to the activity of the starter culture bacteria. These results are in agreement with those of Zedan et al., (2001).

Table 2. Acidity\% and $\mathrm{pH}$ values of functional yoghurt made with different types and percentage of WPC when fresh and during the storage periods up to 21 days at $\sim 5^{\circ} \mathrm{C}$.

\begin{tabular}{|c|c|c|c|c|c|c|c|c|c|c|c|c|}
\hline \multirow{3}{*}{$\begin{array}{l}\text { Storage period } \\
\text { day's }\end{array}$} & \multicolumn{8}{|c|}{ Treatments } & \multirow[b]{2}{*}{ T7 } & \multirow[b]{2}{*}{ T8 } & \multirow[b]{2}{*}{ T9 } & \multirow[b]{2}{*}{ T10 } \\
\hline & C1 & $\mathrm{C2}$ & T1 & T2 & T3 & T4 & T5 & T6 & & & & \\
\hline & \multicolumn{12}{|c|}{ Acidity\% } \\
\hline $\mathbf{F}$ & 0.71 & 0.71 & 0.68 & 0.65 & 0.69 & 0.68 & 0.72 & 0.72 & 0.69 & 0.71 & 0.72 & 0.72 \\
\hline $7 \mathrm{da}$ & 0.76 & 0.75 & 0.73 & 0.77 & 0.75 & 0.76 & 0.76 & 0.76 & 0.72 & 0.75 & 0.77 & 0.76 \\
\hline 14 days & 0.77 & 0.78 & 0.75 & 0.79 & 0.77 & 0.77 & 0.79 & 0.77 & 0.78 & 0.78 & 0.8 & 0.79 \\
\hline \multirow[t]{2}{*}{21 days } & 6 & 0.79 & 0.75 & 0.78 & 0.78 & 0.79 & 0.79 & 0.79 & 0.79 & 0.77 & 0.8 & 0.8 \\
\hline & \multicolumn{12}{|c|}{ pH value } \\
\hline & $\overline{4.44}$ & 4.46 & 40 & 4.4 & 4.43 & 4.42 & 4.26 & 4.2 & 4. & 4.37 & 4.35 & 4.40 \\
\hline $7 \mathrm{~d}$ & 4.29 & 4.31 & 4.32 & 4.40 & 4.27 & 4.26 & 4.17 & 4.23 & 4.30 & 4.21 & 4.25 & 4.31 \\
\hline 14 days & 4.18 & 4.17 & 4.27 & 4.32 & 4.18 & 4.17 & 4.13 & 4.11 & 4.22 & 4.17 & 4.11 & 4.18 \\
\hline 21 days & 4.11 & 4.13 & 4.18 & 4.24 & 4.13 & 4.11 & 4.05 & 4.07 & 4.12 & 4.12 & 3.99 & 4.00 \\
\hline
\end{tabular}

C1: Control (full-fat standardized mixed milk cows and buffalos (1:1) 3\% fat).

$\mathrm{C} 2$ : Control (low-fat mixed milk cows and buffalos $(1: 1) \sim 1.5 \%$ fat).

T1: Low-fat mixed milk cows and buffalos (1:1) 1.5\% fat $+2 \%$ with whey protein.

T2: Low-fat mixed milk cows and buffalos $(1: 1) \sim 1.5 \%$ fat $+3 \%$ with whey protein.

T3: Low-fat mixed milk cows and buffalos $(1: 1) \sim 1.5 \%$ fat $+2 \%$ with whey protein concentrate.

T4: Low-fat mixed milk cows and buffalos $(1: 1) \sim 1.5 \%$ fat $+3 \%$ with whey protein concentrate.

T5: Low-fat mixed milk cows and buffalos (1:1) $1.5 \%$ fat $+2 \%$ with particulated whey protein concentrate at $\mathrm{pH} 3$.

T6: Low-fat mixed milk cows and buffalos $(1: 1) 1.5 \%$ fat $+3 \%$ with particulated whey protein concentrate at $\mathrm{pH} 3$.

T7: Low-fat mixed milk cows and buffalos $(1: 1) 1.5 \%$ fat $+2 \%$ with particulated whey protein concentrate at $\mathrm{pH} 5$.

T8: Low-fat mixed milk cows and buffalos (1:1) $1.5 \%$ fat $+3 \%$ with particulated whey protein concentrate at $\mathrm{pH} 5$.

T9: Low-fat mixed milk cows and buffalos $(1: 1) 1.5 \%$ fat $+2 \%$ commercial whey protein concentrate powder.

T10: Low fat mixed milk cows and buffalos (1:1) $1.5 \%$ fat $+3 \%$ commercial whey protein concentrate powder. 
The $\mathrm{pH}$ values took an opposite trends to that of acidity, the corresponding $\mathrm{pH}$ values of both $\mathrm{T} 3$ and T5 were slightly lower than those of control and other treatments the $\mathrm{pH}$ values of all treatments decreased during the storage period due to the increace of starter activity and acidity, the present results are in agreement with those given by Nahed EL-Wahsh (2013).

\section{Gross chemical composition:-}

Table (3) shows the average gross chemical composition of functional yoghurt made with different types of wpc when fresh and during storage periods up to 21 days. In general the total solid contents of low-fat yoghurt were lower than that of full-fat yoghurt, due to the high fat content of the control full-fat yoghurt.

Table 3. Average of chemical composition of functional yoghurt made with different types and percentages of WPC when fresh and during the storage periods up to 21 days at $\sim 5^{\circ} \mathrm{C}$.

\begin{tabular}{|c|c|c|c|c|c|c|c|c|c|c|c|c|}
\hline \multirow{3}{*}{$\begin{array}{l}\text { Storage } \\
\text { period } \\
\text { (day's) }\end{array}$} & \multicolumn{12}{|c|}{ Treatments } \\
\hline & C1 & $\mathrm{C2}$ & T1 & $\mathbf{T 2}$ & T3 & T4 & T5 & T6 & T7 & T8 & T9 & T10 \\
\hline & \multicolumn{12}{|c|}{ Total solids } \\
\hline Fresh & 13.31 & 12.25 & 11.90 & 12.02 & 11.99 & 12.18 & 11.93 & 12.16 & 11.81 & 11.90 & 11.74 & 11.84 \\
\hline 7 days & 13.35 & 12.37 & 12.08 & 12.06 & 12.14 & 12.33 & 12.05 & 12.23 & 11.99 & 11.99 & 12.07 & 12.19 \\
\hline 14 days & 13.49 & 12.45 & 12.15 & 12.18 & 12.18 & 12.44 & 12.13 & 12.36 & 12.17 & 12.06 & 12.11 & 12.32 \\
\hline 21 days & 13.52 & 12.47 & 12.27 & 12.18 & 12.50 & 12.51 & 12.21 & 12.44 & 12.21 & 12.1 & 12.16 & 12.43 \\
\hline \multicolumn{13}{|c|}{ Protein } \\
\hline Fresh & 3.99 & 3.94 & 3.73 & 3.93 & 3.8 & 3.97 & 3.81 & 3.94 & 3.86 & 3.92 & 3.96 & 4.04 \\
\hline 7 days & 4.03 & 4.01 & 3.80 & 3.98 & 3.91 & 4.03 & 3.9 & 4.02 & 3.9 & 4.01 & 4.02 & 4.08 \\
\hline 14 days & 4.08 & 4.04 & 3.93 & 4.01 & 4.05 & 4.21 & 3.94 & 4.13 & 3.95 & 4.09 & 4.05 & 4.13 \\
\hline 21 days & 4.15 & 4.11 & 3.98 & 4.05 & 4.10 & 4.25 & 4.14 & 4.26 & 4.11 & 4.28 & 4.16 & 4.25 \\
\hline \multicolumn{13}{|c|}{ Ash } \\
\hline Fresh & 0.75 & 0.76 & 0.71 & 0.74 & 0.75 & 0.77 & 0.72 & 0.74 & 0.71 & 0.72 & 0.68 & 0.70 \\
\hline 7 days & 0.79 & 0.78 & 0.78 & 0.78 & 0.79 & 0.82 & 0.75 & 0.75 & 0.73 & 0.76 & 0.73 & 0.74 \\
\hline 14 days & 0.85 & 0.84 & 0.8 & 0.83 & 0.83 & 0.84 & 0.82 & 0.83 & 0.79 & 0.81 & 0.76 & 0.77 \\
\hline 21 days & 0.86 & 0.86 & 0.83 & 0.87 & 0.86 & 0.84 & 0.84 & 0.86 & 0.82 & 0.84 & 0.78 & 0.79 \\
\hline \multicolumn{13}{|c|}{ Fat } \\
\hline Fresh & 3.00 & 1.50 & 1.50 & 1.50 & 1.5 & 1.49 & 1.48 & 1.50 & 1.52 & 1.53 & 1.60 & 1.58 \\
\hline 7 days & 3.02 & 1.51 & 1.52 & 1.50 & 1.5 & 1.49 & 1.49 & 1.50 & 1.56 & 1.53 & 1.68 & 1.69 \\
\hline 14 days & 3.05 & 1.57 & 1.53 & 1.53 & 1.50 & 1.52 & 1.51 & 1.55 & 1.62 & 1.60 & 1.69 & 1.69 \\
\hline 21 days & 3.02 & 1.60 & 1.52 & 1.57 & 1.56 & 1.54 & 1.53 & 1.58 & 1.62 & 1.60 & 1.68 & 1.73 \\
\hline \multicolumn{13}{|c|}{ TVFA } \\
\hline Fresh & 7.67 & 6.33 & 6.83 & 7.33 & 7.17 & 7.83 & 8.00 & 8.67 & 8.17 & 9.00 & 8.50 & 8.83 \\
\hline 7 days & 9.67 & 7.67 & 8.00 & 8.67 & 9.33 & 9.83 & 10.67 & 11.90 & 10.83 & 12.17 & 10.93 & 11.83 \\
\hline 14 days & 12.33 & 9.67 & 10.67 & 11.50 & 12.17 & 12.67 & 12.83 & 13.67 & 13.93 & 15.67 & 13.50 & 15.17 \\
\hline 21 days & 13.67 & 11.67 & 13.00 & 13.33 & 13.67 & 13.90 & 14.83 & 16.67 & 16.83 & 18.67 & 15.67 & 17.67 \\
\hline \multicolumn{13}{|c|}{ Acitaldhyde ( $\mu \mathrm{g} / \mathbf{1 0 0 g})$} \\
\hline Fresh & 17.66 & 17.65 & 17.71 & 17.73 & 17.69 & 17.70 & 17.75 & 17.78 & 17.76 & 17.79 & 17.62 & 17.69 \\
\hline 7 days & 17.83 & 17.71 & 17.74 & 17.79 & 17.74 & 17.8 & 17.83 & 17.9 & 17.85 & 17.93 & 17.64 & 17.70 \\
\hline 14 days & 17.57 & 17.59 & 17.71 & 17.60 & 17.59 & 17.58 & 17.62 & 17.73 & 17.71 & 17.73 & 17.58 & 17.63 \\
\hline 21 days & 17.56 & 17.55 & 17.54 & 17.57 & 17.55 & 17.56 & 17.58 & 17.62 & 17.59 & 17.63 & 17.5 & 17.53 \\
\hline
\end{tabular}

C1: Control (full-fat standardized mixed milk cows and buffalos (1:1) 3\%fat).

C2: Control (low-fat mixed milk cows and buffalos (1:1) 1.5\%fat).

T1: Low-fat mixed milk cows and buffalos $(1: 1) \sim 1.5 \%$ fat $+2 \%$ with whey protein.

T2: Low-fat mixed milk cows and buffalos (1:1) 1.5\% fat $+3 \%$ with whey protein.

T3: Low-fat mixed milk cows and buffalos $(1: 1) \sim 1.5 \%$ fat $+2 \%$ with whey protein concentrate.

T4: Low-fat mixed milk cows and buffalos $(1: 1) \sim 1.5 \%$ fat $+3 \%$ with whey protein concentrate.

T5: Low-fat mixed milk cows and buffalos $(1: 1) 1.5 \%$ fat $+2 \%$ with particulated whey protein concentrate at $\mathrm{pH} 3$.

T6: Low-fat mixed milk cows and buffalos $(1: 1) 1.5 \%$ fat $+3 \%$ with particulated whey protein concentrate at $\mathrm{pH} 3$.

T7: Low-fat mixed milk cows and buffalos $(1: 1) 1.5 \%$ fat $+2 \%$ with particulated whey protein concentrate at $\mathrm{pH} 5$.

T8: Low-fat mixed milk cows and buffalos $(1: 1) 1.5 \%$ fat $+3 \%$ with particulated whey protein concentrate at $\mathrm{pH} 5$.

T9: Low-fat mixed milk cows and buffalos (1:1) $1.5 \%$ fat $+2 \%$ commercial whey protein concentrate powder.

T10: Low fat mixed milk cows and buffalos (1:1) $1.5 \%$ fat $+3 \%$ commercial whey protein concentrate powder. 
The total solids of functional yoghurt containing wpc were lower than the corresponding values of the control either when fresh or along the storage periods up to 21 days this could be attributed to the low solids content of the wpc and high water holding capacity of wpc. On the other hand, the total solid of the control and different treatments increased gradually all over the storage periods up to 21 days and this could be due to the limited water loos during storage periodes Shenana et al., (2007).

The protein content of functional yoghurt was slightly increased in a proportional rate with the addition of wpc. This can be attributed to the high protein content of wpc. Shenana et al., (2007).

The fat and ash contents of the functional yoghurt was nearly not affected by the addition of wpc as its almost free of fat Mehanna and Gone (1988).

The protein, fat and ash contents of control and different treatments of functional yoghurt were slightly increased all over the storage periods up to 21 days corresponding to the increase of total solids of different treatments Shenana et al., (2007).

The total volatile fatty acids contents of control and functional yoghurt from different treatments were gradually increased all over the storage period up to 21 days. This can be related to the growth and activity of the lactic acid starter culture similar trend was reported by Shenana et al (2007) and ELDahma (2018). The produced functional yoghurt with wpc (T4) recorded higher (TVFA) content comparing with the control and the other different treatments.

The acetaldehyde content of controls and functional yoghurt of different treatments were gradually decreased by prolonging the storage periods up to 21 days at $\sim 5^{\circ} \mathrm{C}$. This decreased attributed to acetaldehyde is transitory component, where it begins in decrease after the fermentation is complete in the first 5 hour of storage. (Hamad et al., 2016).

\section{Rheological properties:}

Table (4) shows the physical properties of functional yoghurt with different types of whey concentrate when fresh and during storage at $5^{\circ} \mathrm{C}$ up to 21days. The results of viscosity recorded proportional increased in the values of the treated functional yoghurt with different levels of wpc when fresh and also proportional to the progress of the storage time. This could be attributed to the presence of $\alpha$-lactalbumin and $\beta$-lactoglobulin which play a major role as a gelatinizing agent due to presence of free sulphydryl groups. Increasing of added whey proteins might have improved the rheological characterestics of produced functional yoghurt the obtained results are in agreement with those of. ElAlfy et al., (2018).

Table 4. Physical properties of functional yoghurt made with different types and percentage of WPC when fresh and during storage at $\sim 5^{\circ} \mathrm{C}$.

\begin{tabular}{|c|c|c|c|c|c|c|c|c|c|c|c|c|}
\hline \multirow{3}{*}{$\begin{array}{l}\text { Storage } \\
\text { periods } \\
\text { (day's) }\end{array}$} & \multicolumn{12}{|c|}{ Treatments } \\
\hline & $\mathrm{C1}$ & $\mathrm{C2}$ & T1 & T2 & T3 & T4 & T5 & T6 & T7 & T8 & T9 & T10 \\
\hline & \multicolumn{12}{|c|}{ Viscosity (CP) } \\
\hline Fresh & 16523 & 16133 & 16050 & 16540 & 16453 & 16613 & 16556 & 16456 & 16520 & 16570 & 15923 & 16536 \\
\hline 7 days & 16563 & 16400 & 16426 & 16416 & 16560 & 16580 & 16466 & 16560 & 16596 & 16630 & 15920 & 16670 \\
\hline 14 days & 16486 & 16253 & 16400 & 16610 & 16533 & 16583 & 16343 & 16396 & 16343 & 16586 & 15746 & 16580 \\
\hline 21 days & 16606 & 16600 & 16563 & 16623 & 16600 & 16660 & 16473 & 16566 & 16453 & 16600 & 15910 & 16650 \\
\hline \multicolumn{13}{|c|}{ Curd synersis $\left(\mathrm{g100g}^{-1}\right) 120 \mathrm{~min}$} \\
\hline Fresh & 31.81 & 31.41 & 25.82 & 29.64 & 28.09 & 30.01 & 27.95 & 24.82 & 27.85 & 26.71 & 24.05 & 26.90 \\
\hline 7 days & 33.89 & 33.89 & 28.51 & 31.01 & 29.77 & 30.16 & 27.92 & 25.86 & 28.32 & 27.92 & 25.57 & 26.79 \\
\hline 14 days & 35.15 & 34.30 & 29.43 & 31.11 & 32.35 & 32.02 & 30.91 & 30.40 & 31.03 & 32.77 & 28.90 & 28.48 \\
\hline 21 days & 36.96 & 35.82 & 30.88 & 32.17 & 32.78 & 34.36 & 31.78 & 30.80 & 33.40 & 32.50 & 29.63 & 30.23 \\
\hline \multicolumn{13}{|c|}{ Water holding capacity (WHC \%) } \\
\hline Fresh & 48.85 & 48.15 & 46.11 & 44.00 & 47.75 & 47.97 & 51.77 & 49.88 & 49.15 & 50.00 & 49.24 & 48.17 \\
\hline 7 days & 47.5 & 46.34 & 44.92 & 43.14 & 46.00 & 46.88 & 48.25 & 47.97 & 45.76 & 46.66 & 45.60 & 45.95 \\
\hline 14 days & 46.71 & 44.63 & 41.84 & 41.19 & 41.87 & 44.68 & 45.16 & 43.28 & 42.36 & 43.95 & 44.26 & 43.46 \\
\hline 21 days & 44.08 & 41.73 & 40.74 & 38.81 & 41.51 & 42.78 & 44.80 & 42.31 & 41.50 & 42.43 & 41.04 & 40.94 \\
\hline
\end{tabular}

C1: Control (full-fat standardized mixed milk cows and buffalos (1:1) 3\%fat).

C2: Control (low-fat mixed milk cows and buffalos (1:1) 1.5\%fat).

T1: Low-fat mixed milk cows and buffalos $(1: 1) \sim 1.5 \%$ fat $+2 \%$ with whey protein.

T2: Low-fat mixed milk cows and buffalos (1:1) 1.5\%fat $+3 \%$ with whey protein.

T3: Low-fat mixed milk cows and buffalos $(1: 1) \sim 1.5 \%$ fat $+2 \%$ with whey protein concentrate.

T4: Low-fat mixed milk cows and buffalos $(1: 1) \sim 1.5 \%$ fat $+3 \%$ with whey protein concentrate.

T5: Low-fat mixed milk cows and buffalos $(1: 1) 1.5 \%$ fat $+2 \%$ with particulated whey protein concentrate at $\mathrm{pH} 3$.

T6: Low-fat mixed milk cows and buffalos $(1: 1) 1.5 \%$ fat $+3 \%$ with particulated whey protein concentrate at $\mathrm{pH} 3$.

T7: Low-fat mixed milk cows and buffalos $(1: 1) 1.5 \%$ fat $+2 \%$ with particulated whey protein concentrate at $\mathrm{pH} 5$.

T8: Low-fat mixed milk cows and buffalos $(1: 1) 1.5 \%$ fat $+3 \%$ with particulated whey protein concentrate at $\mathrm{pH} 5$.

T9: Low-fat mixed milk cows and buffalos $(1: 1) 1.5 \%$ fat $+2 \%$ commercial whey protein concentrate powder.

T10: Low fat mixed milk cows and buffalos (1:1) $1.5 \%$ fat $+3 \%$ commercial whey protein concentrate powder. 
On the other hand, the results recorded a slower synersis and higher water holding capacity values comparing with the control. The decrease of synersis was proportional to the increase of whey protein concentrates which increases water holding capacity due to the increase of protein matrix. The present results agree with that obtained by (Das and Seth, 2017) and El-Alfy et al., (2018).

\section{Microbiological properties:}

\section{Total viable bacterial counts (TVC)}

Table (5) shows that the total viable bacterial counts (TVC) of functional yoghurt from different types of wpc. TVC were not affected by both two levels of wpc, added to different treatments for fresh functional yoghurt. The corresponding number of TVC were slightly increased during storage for all the treatments. The same trend of results was also observed during the storage periods of functional yoghurt up to 21 days but the high increase of viable counts were observed within the first 7 days of storage, then followed by slightly decrease again among different treatments up to the end of storage and this may be attributed to the development of acidity by the starter cultures which affect the activity of bacteria. EL-Wahsh (2013).

The yeasts and moulds were not detected in all fresh yoghurt either the control or functional and within the first 7 days of storage very low counts less than $10 \mathrm{cfu}$ of yeasts and moulds were detected after 14 and 21 days of storage, respectively. Similar results were obtained EL-Wahsh (2013).

Coliform groups were not detected of all functional yoghurt when fresh and all over the storage periods. This indicates the good sanitary and hygienic conditions during making the products Shenana et al., (2007).

Table 5. Microbiological aspects $(\log \mathrm{cfu} / \mathrm{ml})$ of functional yoghurt made with different types and percentage of WPC when fresh and during the storage periods up to 21 days at $\sim 5^{\circ} \mathrm{C}$.

\begin{tabular}{|c|c|c|c|c|c|c|c|c|c|c|c|c|}
\hline \multirow{3}{*}{$\begin{array}{c}\text { Storage } \\
\text { periods } \\
\text { (day's) }\end{array}$} & \multicolumn{12}{|c|}{ Treatments } \\
\hline & C1 & $\mathrm{C2}$ & T1 & $\mathbf{T 2}$ & T3 & T4 & T5 & T6 & T7 & T8 & T9 & T10 \\
\hline & \multicolumn{12}{|c|}{ Total viable bacterial count (TVC) } \\
\hline Fresh & 7.00 & 7.14 & 7.05 & 6.99 & 6.88 & 6.73 & 6.87 & 6.91 & 7.05 & 7.04 & 6.73 & 7.12 \\
\hline 7 days & 7.10 & 7.40 & 7.34 & 7.24 & 7.20 & 7.42 & 7.37 & 7.07 & 7.16 & 7.42 & 7.23 & 7.47 \\
\hline 14 days & 6.88 & 7.37 & 6.69 & 7.23 & 7.12 & 7.13 & 7.20 & 7.03 & 7.09 & 7.20 & 7.05 & 7.30 \\
\hline 21 days & 6.70 & 6.92 & 6.80 & 6.88 & 6.87 & 6.16 & 6.71 & 6.52 & 6.99 & 7.04 & 6.71 & 7.12 \\
\hline
\end{tabular}

C1: Control (full-fat standardized mixed milk cows and buffalos (1:1) 3\%fat).

C2: Control (low-fat mixed milk cows and buffalos (1:1) 1.5\%fat).

T1: Low-fat mixed milk cows and buffalos $(1: 1) \sim 1.5 \%$ fat $+2 \%$ with whey protein.

T2: Low-fat mixed milk cows and buffalos $(1: 1) \sim 1.5 \%$ fat $+3 \%$ with whey protein.

T3: Low-fat mixed milk cows and buffalos $(1: 1) \sim 1.5 \%$ fat $+2 \%$ with whey protein concentrate.

T4: Low-fat mixed milk cows and buffalos $(1: 1) \sim 1.5 \%$ fat $+3 \%$ with whey protein concentrate.

T5: Low-fat mixed milk cows and buffalos $(1: 1) 1.5 \%$ fat $+2 \%$ with particulated whey protein concentrate at $\mathrm{pH} 3$.

T6: Low-fat mixed milk cows and buffalos $(1: 1) 1.5 \%$ fat $+3 \%$ with particulated whey protein concentrate at $\mathrm{pH} 3$.

T7: Low-fat mixed milk cows and buffalos $(1: 1) 1.5 \%$ fat $+2 \%$ with particulated whey protein concentrate at pH5.

T8: Low-fat mixed milk cows and buffalos $(1: 1) 1.5 \%$ fat $+3 \%$ with particulated whey protein concentrate at $\mathrm{pH} 5$.

T9: Low-fat mixed milk cows and buffalos $(1: 1) 1.5 \%$ fat $+2 \%$ commercial whey protein concentrate powder.

T10: Low- fat mixed milk cows and buffalos $(1: 1) 1.5 \%$ fat $+3 \%$ commercial whey protein concentrate powder.

\section{Sensory evaluation:}

All prepared functional yoghurt treatments were evaluated when fresh and during interval storage ( $5^{\circ} \mathrm{C}$ ) up to 21 days for the different organoleptic properties including flavour, body \& texture and appearance. The panelist score are presented in Table (6). In general it can be concluded that the different treatments recorded slightly higher score than the control, also the functional yoghurt containing whey protein concentrate (T5) ranked the highest score points when fresh and during the first 7 days of storage. After 14 and 21 days of storage the organoleptic scores of all samples were gradually decreased, and the lowest values were observed at 21 days of storage this could be attributed to the increase of acid development as recorded to Shenana et al., (2007) and El-Alfy et al., (2018).

\section{Conclusion}

From such study it could be conclude that different types of wpc can be used successfully in manufacture of functional yoghurt with good physical properties that bear resemblance to that of full-fat yoghurt. Moreover; improving the sensorial qualities and physico-chemical characteristics of the produced functional yoghurt. 
Table 6. Sensory evaluation of functional yoghurt with different types and percentages of WPC when fresh and during storage periods up to 21 days at $\sim 5^{\circ} \mathrm{C}$.

\begin{tabular}{|c|c|c|c|c|c|c|c|c|c|c|c|c|}
\hline \multirow{3}{*}{$\begin{array}{l}\text { Storage } \\
\text { periods } \\
\text { (day's) }\end{array}$} & \multicolumn{12}{|c|}{ Treatments } \\
\hline & C1 & $\mathrm{C2}$ & T1 & T2 & T3 & T4 & T5 & T6 & $\mathbf{T 7}$ & T8 & T9 & T10 \\
\hline & \multicolumn{12}{|c|}{ Flavour (50) } \\
\hline Fresh & 46.33 & 45.67 & 44.67 & 45.67 & 45.00 & 46.00 & 45.67 & 46.00 & 47.33 & 47.67 & 43.33 & 44.33 \\
\hline 7 days & 47.00 & 45.67 & 45.33 & 46.00 & 45.00 & 46.67 & 48.00 & 46.67 & 48.00 & 49.33 & 45.67 & 46.67 \\
\hline 14 days & 44.67 & 45.33 & 45.00 & 47.33 & 42.67 & 44.33 & 45.33 & 45.00 & 46.00 & 46.00 & 40.33 & 41.33 \\
\hline 21 days & 41.00 & 41.67 & 41.33 & 40.33 & 41.67 & 43.67 & 44.00 & 43.33 & 44.00 & 45.00 & 37.67 & 39.33 \\
\hline \multicolumn{13}{|c|}{ Body\&texture (30) } \\
\hline Fresh & 26.00 & 27.00 & 27.00 & 27.67 & 26.67 & 27.00 & 28.00 & 28.00 & 27.00 & 28.00 & 27.67 & 27.00 \\
\hline 7 days & 27.00 & 27.33 & 27.67 & 28.00 & 27.67 & 28.00 & 27.67 & 28.33 & 28.33 & 29.00 & 27.67 & 28.00 \\
\hline 14 days & 25.33 & 26.33 & 27.00 & 27.00 & 26.00 & 26.00 & 26.00 & 26.67 & 26.67 & 27.67 & 22.33 & 23.33 \\
\hline 21 days & 24.00 & 23.00 & 21.00 & 23.00 & 24.00 & 24.00 & 25.33 & 26.00 & 25.33 & 26.33 & 22.00 & 20.67 \\
\hline \multicolumn{13}{|c|}{ Appearance (10) } \\
\hline Fresh & 9.00 & 9.00 & 9.00 & 9.00 & 9.00 & 9.00 & 9.00 & 9.00 & 10.00 & 10.00 & 9.00 & 10.00 \\
\hline 7 days & 9.00 & 9.00 & 9.00 & 9.00 & 9.00 & 9.00 & 9.00 & 10.00 & 10.00 & 10.00 & 10.00 & 10.00 \\
\hline 14 days & 9.00 & 9.00 & 9.00 & 9.00 & 9.00 & 9.00 & 9.00 & 10.00 & 10.00 & 10.00 & 10.00 & 10.00 \\
\hline 21 days & 9.00 & 9.00 & 9.00 & 9.00 & 9.00 & 9.00 & 9.00 & 9.00 & 9.00 & 9.00 & 9.00 & 9.00 \\
\hline \multicolumn{13}{|c|}{ Wheying off (10) } \\
\hline Fresh & 10.00 & 10.00 & 10.00 & 10.00 & 10.00 & 10.00 & 10.00 & 10.00 & 10.00 & 10.00 & 10.00 & 10.00 \\
\hline 7 days & 10.00 & 10.00 & 10.00 & 10.00 & 10.00 & 10.00 & 10.00 & 10.00 & 10.00 & 10.00 & 10.00 & 10.00 \\
\hline 14 days & 10.00 & 10.00 & 10.00 & 10.00 & 10.00 & 10.00 & 10.00 & 10.00 & 10.00 & 10.00 & 10.00 & 10.00 \\
\hline 21 days & 10.00 & 10.00 & 10.00 & 10.00 & 9.00 & 9.00 & 9.00 & 10.00 & 9.00 & 9.00 & 9.00 & 9.67 \\
\hline \multicolumn{13}{|c|}{ Total score (100) } \\
\hline Fresh & 91.33 & 91.67 & 90.67 & 92.33 & 90.67 & 92.00 & 92.67 & 93.00 & 94.33 & 95.67 & 90.00 & 91.33 \\
\hline 7 days & 93.00 & 92.00 & 92.00 & 93.00 & 91.67 & 93.67 & 94.67 & 95.00 & 96.33 & 98.33 & 93.33 & 94.67 \\
\hline 14 days & 89.00 & 90.67 & 91.00 & 93.33 & 87.67 & 89.33 & 90.33 & 91.67 & 92.67 & 93.67 & 82.67 & 84.67 \\
\hline 21 days & 84.00 & 83.67 & 81.33 & 82.33 & 83.67 & 85.67 & 87.33 & 88.33 & 87.33 & 89.33 & 77.67 & 78.67 \\
\hline
\end{tabular}

C1: Control (full-fat standardized mixed milk cows and buffalos (1:1) 3\%fat).

C2: Control (low-fat mixed milk cows and buffalos (1:1) 1.5\%fat).

T1: Low-fat mixed milk cows and buffalos $(1: 1) \sim 1.5 \%$ fat $+2 \%$ with whey protein.

T2: Low-fat mixed milk cows and buffalos $(1: 1) \sim 1.5 \%$ fat $+3 \%$ with whey protein.

T3: Low-fat mixed milk cows and buffalos $(1: 1) \sim 1.5 \%$ fat $+2 \%$ with whey protein concentrate.

T4: Low-fat mixed milk cows and buffalos $(1: 1) \sim 1.5 \%$ fat $+3 \%$ with whey protein concentrate.

T5: Low-fat mixed milk cows and buffalos $(1: 1) 1.5 \%$ fat $+2 \%$ with particulated whey protein concentrate at $\mathrm{pH} 3$.

T6: Low-fat mixed milk cows and buffalos $(1: 1) 1.5 \%$ fat $+3 \%$ with particulated whey protein concentrate at $\mathrm{pH} 3$.

T7: Low-fat mixed milk cows and buffalos $(1: 1) 1.5 \%$ fat $+2 \%$ with particulated whey protein concentrate at $\mathrm{pH} 5$.

T8: Low-fat mixed milk cows and buffalos $(1: 1) 1.5 \%$ fat $+3 \%$ with particulated whey protein concentrate at $\mathrm{pH} 5$.

T9: Low-fat mixed milk cows and buffalos $(1: 1) 1.5 \%$ fat $+2 \%$ commercial whey protein concentrate powder.

T10: Low- fat mixed milk cows and buffalos (1:1) $1.5 \%$ fat $+3 \%$ commercial whey protein concentrate powder.

\section{References}

AOAC, (2012). Official methods of Analysis of Association of Official Analytical Chemists $19^{\text {th }}$ ed., Published by AOAC International, Gaithersburg, Maryland, USA.

APHA, (1992). Standard methods for the examination of dairy products. American Publ. Health Assoc. Inc. 16 ${ }^{\text {th }}$ Ed., Washington D.C.

Barbosa,A.S; Florentino,E.R; Florêncio, I.M. and Araújo,A.S. (2010). Utilização do soro como substrato para produção de aguardente: estudo cinético da produção de etanol. Rev Verde Agroecol Desenvolv Sustent 5:7-25.

Bhattacharjee, S.; Bhattacharjee, C.; and Datta, S. (2006) Studies of the fractionation of $\beta$ lactoglobulin from casein whey using ultrafiltration and ion-exchange membrane chromatography. Journal of Membrane Science, 275, 141-150.
BSI, (2010). Dried milk: determination of titratable acidity (Reference method) ISO, 6091, British Standards Institution, London, U.K.

Codex Alimentarius commission of FAO/WHO $26^{\text {th }}$ session (2003). Rome, Italy

Das, A. and Seth, R. (2017). Chemical compositional analysis and physical attributes of curd fortified with bovine colostrum whey powder. Inter. J. Chemical Stud., 5(1): 334-338.

El-Alfy, M.B.; El-Nagar G.F.; Abd El-Aty A.M.; Essawy E.A. and Hammad M.N. A. (2018). Making of fortified yoghurt with colostrum. Egypt. J. of Appl. Sci., 33 (3):61-75.

El-Dahma, M.M.D. (2018). Effect of chitosan on the properties of some soft cheese. Ph.D. Thesis, Dairy Sci. \& Tech., Fac. Agric., Alex. Uni., Egypt.

EL-Wahsh, N. A (2013). A study on production and attributes of some dairy products as functional 
foods. M.Sc. thesis, Fac. Agric., Tanta Uni., Egypt.

Hamad, M.N.F.; Ismail, M.M.; El-Kadi, S.M.L. and Zidan, M.Sh. (2016). Chemical composition, microbial properties and sensory evaluation of bio-yoghurt made from amixture of cow and coconut milk and honey. Inter.

J.

Sci. Res. in Sci. and Tech., 2(5):246-260.

Hamad, M.N.F.; Ismail, M.M.; El-Kadi, S.M.L. and Zidan, M.Sh. (2016). Chemical composition, microbial properties and sensory evaluation of bio-yoghurt made from admixture of cow and coconut milk and honey. Inter. J. Sci. Res. in Sci. and Tech., 2(5):246-260.

International Dairy Federation (IDF), (1990). Milk and milk products: Enumeration of Yeasts and Moulds (Colony count technique at $25^{\circ} \mathrm{C}$ ). IDF: $94 \mathrm{~B}$.

International Dairy Federation (IDF), (1991). Butter, fermented milks and fresh cheese. Enumeration of contaminating microorganisms. Colony count technique at $30^{\circ} \mathrm{C}$. IDF, 153 .

Keogh, M.K. and O'Kennedy , B.T. (1998). Rheology of stirred yoghurts as affected by added milk fat, protein and hydrocolloids. J. Food Sci., 63(1), 108-112.

Kosikowski, F. V. (1984). Cheese and Fermented Milk Food. $2^{\text {nd }}$ Ed., Cornell Univ., Ithaca, New York, USA.

Laiho, S.; Williams, R.P.W.; Poelman, A.; Appelqvist, I. and Logan, A. (2017).Effect of whey protein phase volume on the tribology, rheology and sensory properties of fat-free stirred yoghurts. Food Hydrocolloids, 67:166-177.

Less, G.J. and Jago, G.R. (1969). Methods for the estimation of acetaldehyde in cultured dairy products. Australian. J. Dairy Technol. 24:181185.

Mehanna, N.M. and Gonc, S. (1988) Manufacture of yoghurt from milk fortified with whey powder. Egyptian J. Dairy Sci. 16: 239.

Mikal Stijepić,.D.; and Glušac, J. (2012). Production of low fat yoghurt enriched with different functional ingredients. Quality of Life, 5(1-2).

Petersen, B.L.; Dave, R.I.; McMahon, D.J.; Oberg, C.J. and Broadbent, J.R. (2000). Influence of capsular and ropy exopolysaccharide producing Streptococcus thermophilus on mozzarella cheese and cheese whey. J. Dairy Sci., 83(9):1952-1956.

Sandoval-Castilla, O.C.; Lobato-Calleros, E.; Aguirre-Mandujano, and E. J. Vernon-Carte (2004) Microstructure and texture of yoghurt as influenced by fat replacers. Int. Dairy J. 14:151159.

Shenana, M.E.; El-Nagar, G.F.; Safinaz, ElShibiny and Sania, M.Abdou (2007). preparation and use of whey protein/carragennan particulate in making Low-fat yoghurt.Egyption Journal of Dairy Science, Vol.3.pp.185-193.

Tamime, A.Y. and Deeth, H.C. (1980). Yoghurt: Technology and bio-chemistry. J. Food Prot., 43:939-942.

Tamime, A.Y. and Robinson, R.K. (1999). Yoghurt: Science and Technology (2 ${ }^{\text {nd }}$ ed.) .Cambridge, UK: Wood head p ublishing Ltd.

Zedan, M.A. ; Zedan, A. N. ; Kebary, K. M. K. and Mahmoud, S.F. ( 2001). Effects of fortification of cow's milk with acetylated whey protein concentrates on the quality of set yoghurt. Egyptian J. Dairy Sci. 29: 285.

$$
\begin{aligned}
& \text { إستخدام مركزات بروتينات الشرش في تطبيقات أغذية الألبان الوظيفية }
\end{aligned}
$$

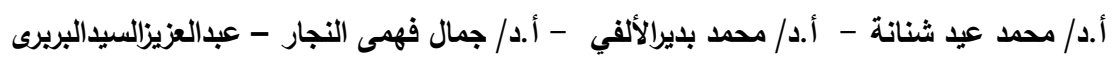

$$
\begin{aligned}
& \text { قسم الألبان - كلية الزراعة بمشتهر - جامعة بنها. }
\end{aligned}
$$

تهدف هذه الدراسة الي تصنيع زيادي وظيفي بإضافة أنواع مختلفة من مركزات بروتينات الشرش ودراسة التركيب الكيماوي

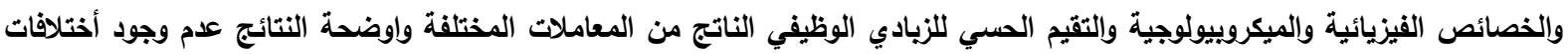
معنوية في الحموضة والأس الهيدروجيني والجوامد الكلية والبروتين والدهن والأحماض الدهنية الطيارة الكلية سواء خلال فترات التخزين او بين والهين المعاملات المختلفة أيضا أوضحت النتائج ان المعاملة T8 أعلي في نسبة الأحماض الدهنية الطيارة الكلية والأسيتالدهيد ويليها المعاملة T10 وهي طازجة وخلال فترات التخزين المختلفة علي درجات حرارة 50م كما ان هناك خصائص حيث للمنتج والتي إنعكست في زيادة اللزوجة و والتي تأثرت بكميات مركزات بروتينات الثرش المضافة وعلي الجانب الأخر أظهر التقيم الحسي خصائص جيدة للزيادي

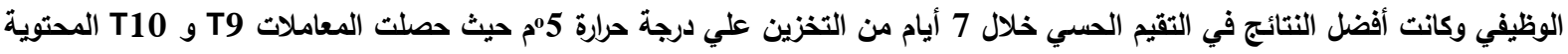
علي 2 و 3 \% من مركزات بروتينات الشرش أعلي درجات تحكيم حسي وهي 93.33 و 94.33 علي التوالي. 